\title{
IDIOPATHIC ESOPHAGEAL ACHALASIA: A STUDY OF ETIOLOGY AND PROFILE OF THE PATIENTS
}

\author{
Acalásia idiopática do esôfago: análise da história clínica e antecedentes na etiologia e perfil \\ dos pacientes
}

\author{
Gustavo Carvalho de OLIVEIRA, Luiz Roberto LOPES, João de Souza COELHO-NETO
}

Trabalho realizado na Disciplina de Moléstias do Aparelho Digestivo do Departamento de Cirurgia da Faculdade de Ciências Médicas da Universidade Estadual de Campinas, Campinas, SP, Brasil

HEADINGS - Esophageal achalasia. Esophagus. Esophageal diseases. Esophageal motility disorders.

\section{Correspondence:}

Luiz Roberto Lopes, Rua Amélia Maria de Paula Venturini, 365, Parque das Universidades CEP 13086-061, Campinas, SP, Brasil.

Fonte de financiamento: não há Conflito de interesses: não há

Recebido para publicação: 14/07/2009 Aceito para publicação: 22/01/2010

DESCRITORES - Acalásia esofágica. Esôfago. Esofagopatias. Transtornos da motilidade esofágica.
ABSTRACT - Background - The idiopathic esophageal achalasia is a disease of unknown etiology, characterized by esophageal aperistalsis and failure of its lower sphincter with dysphagia. Its etiology factors includes: esophageal gastric junction obstruction, degeneration of Auerbach's plexus, virus infection, congenital origin, autoimmune affection and injury by toxic agent. The achalasia diagnosis is reached after excluding Chagas disease possibilities, which includes seronegative results for Trypanosoma cruzi, absence of megacolon and epidemiology for Chagas disease. Aim - To characterize the disease and propose hypothesis concerning its etiology and associated factors. Methods - Review of medical records from 78 patients operated at the Hospital de Clinicas da Unicamp obstruction between 1989 and 2005 and the subsequent interview, using directed questionnaire, reaching for common data between them and emphasizing history, possible co-morbidities and associated factors. In the group of 78 records collected it was possible to contact and interview 33 patients. Results - The main findings of this study were: 1) presence of a triggering relevant emotional factor before the symptoms (80\%) and over $30 \%$ with psychiatric and/or psychological treatment reported; 2) typical childhood infections highly prevalent ( $88 \%$ measles, varicella, rubella); 3) possible associations with: exposure to chemicals, especially herbicides; other diseases of the gastrointestinal tract, autoimmune diseases, genetic propensity and other changes in the nervous system highlighting the seizures. Conclusions: The idiopathic esophageal achalasia is probably an autoimmune disease, which seems to be highly related to emotional problems.

RESUMO - Racional - Acalásia idiopática do esôfago é doença de etiologia desconhecida, caracterizada por não relaxamento do esfíncter esofágico inferior provocando disfagia. As causas estudadas incluem: obstrução na junção esôfagogástrica, degeneração do plexo nervoso intramural, infecção por vírus, doença de origem congênita, afecção autoimune e lesão por agente tóxico. O diagnóstico é feito após a exclusão de doença chagásica, encontrando-se sorologias negativas, ausência de megacólon e antecedentes epidemiológicos negativos para Chagas. Objetivo - Avaliar a caracterização da doença e elaboração de hipóteses relativas à sua etiologia. Métodos Foram levantados prontuários de 78 pacientes operados no Hospital de Clínicas da Unicamp entre 1989 e 2008 com uso de questionário direcionado, estudando-se os dados comuns entre eles, enfatizando a história clínica, possíveis co-morbidades e fatores associados. Destes, foram entrevistados 33 doentes para obtenção e avaliação de dados. Resultados - Os principais achados foram: 1) presença de um fator emocional desencadeante dos sintomas (cerca de $80 \%$ ) e mais de $30 \%$ com tratamento psiquiátrico/ psicológico declarados; 2 ) infecções típicas da infância muito prevalente (88\% sarampo, varicela, rubéola ou outras); 3) possíveis associações a: exposição a químicos, em especial herbicidas; outras doenças do trato gastrintestinal; doenças auto-imunes; pré-disposição genética; outras alterações no sistema nervoso destacadamente as convulsões. Conclusões: A acalasia idiopática do esôfago é doença de origem provavelmente auto-imune, e associada a fatores emocionais. 
INTRODUCTION

T he idiopathic esophageal achalasia (IEA) is a disease of unknown etiology, characterized by esophageal aperistalsis and failure of its lower sphincter, making it difficult to swallow, causing dysphagia ${ }^{20}$. The studied causes include: obstruction in the esophageal gastric junction, degeneration of Auerbach's plexus, virus infection, congenital origin, autoimmune ${ }^{15}$ affection and injury by toxic agent.

The degeneration of Auerbach plexus of the esophagus determines the absence of peristalsis at the level of body of the organ as well as no aperture of its lower sphincter (achalasia) in response to swallowing. Consequently, an esophageal stasis occurs and, initially, motor incoordination and dilatation ${ }^{4}$. Besides the Chagas disease (the only etiologic factor proven), its recognized that drugs may determine plexular lesion.

The congenital dilatation has been described in several dog breeds, but the proof of inherited megaesophagus in humans is thwarted by its scarcity ${ }^{4}$. Among the few cases observed stand out monozygotic twins with alchalasia ${ }^{23}$ and suggestion of transmission from father to son ${ }^{2}$.

In some of the cases observed, achalasia was present in children descendant from consanguineous relations ${ }^{15}$. In a more recent research, Zilberstein, et al. ${ }^{25}$, found nonchagasic twins developing typical symptoms of achalasia ${ }^{25}$. These same authors considered idiopathic achalasia has expressions and symptoms similar to Chagas Disease.

The diagnosis of achalasia is made after excluding a possible chagasic origin of the disease, in other words, there must be seronegative results for Trypanosoma cruzi, no association what so ever to megacolon or any associated intestinal illnesses and negative epidemiological precedent for Chagas disease ${ }^{1,17}$.

Comparatively, among idiopathic and chagasic achalasia there are similarities and differences in a few points. The destruction of the esophagus intramural nervous plexus, even though there is no consensus, is considered similar in both cases, as shown by Herbella, et al. ${ }^{14}$. The lower sphincter is, usually, more hypertonic in idiopathic esophageal achalasia than it is in chagasic one. On the other hand, the dilatation of the esophagus is more intense in the second ${ }^{14}$.

The duration of dysphagia is a relevant differential factor between the two diseases which is more durable in chagasic patients, possibly due to the slower development ${ }^{5,14}$. Although the incidence of cancer was quite low in all cases of both diseases, there was a higher occurrence in chagasic patients due to the duration of the dysphagia, a risk factor ${ }^{14}$.

The physiopathology of idiopathic esophageal achalasia seems to indicate a previous inflammation of the myenteric nervous plexus of the esophagus developed to a posterior chronic autoimmune response in patients with larger genetic propensity which, in sequence, would raze this esophageal denervation ${ }^{20}$. There are also chances of damages in the nervous system, weakening the Auerbach's intramural plexus directly.

The inflammation that results from the autoimmune response may be due to virus infection and cases in which Guillard Barré syndrome (demyelinization) previously occurred. The genetic association was reported in a few cases $^{2,15,23}$ among which monozygotic twins, whose parents manifested consanguinity. As to the autoimmune response, besides the described sequence of chronic inflammation, there are publications that relate a higher elevation of the HLA Class II antigen in achalasia patients. These are the same molecules associated to lupus erythematosus, Sjogren syndrome and many other systemic autoimmune diseases ${ }^{23}$.

Research conducted in the Hospital de Clínicas da Unicamp pointed interesting data about idiopathic achalasia. The prevalence found was of $21 \%$ (relatively high), the duration of dysphagia in years was less then half of the chagasic achalasia cases $^{19}$, the mean age was also lower: 37,6 (49,9 years in chagasic) $)^{3,19}$.

The aim of this study is to characterize the disease and propose hypothesis concerning its etiology and associated factors.

\section{METHODS}

The achievement and analysis of the clinical history and precedents from patients carrying idiopathic esophageal achalasia in this paper was approved by the Committee of Ethics in Research of the Faculty of Medical Sciences, Unicamp (179/2007).

Records from 78 operated patients suffering from idiopathic achalasia have been raised since 1989 until 2008. Among them, 33 patients were interviewed, answered a elaborated questionnaire and had their data noted, based on: age, gender, nationality, average duration of the dysphagia, serology for Chagas disease, other relevant or associated illnesses, staging of megaesophagus, applied surgery and possible complications, satisfaction after surgery, recurrence/maintenance or not of the symptoms. The classification of megaesophagus used was the one proposed by Mascarenhas (1958) ${ }^{18}$, considering the esophageal diameter (radiographic findings), varying from I to IV. To consider a patient with idiopathic esophageal achalasia, he must have had two negative serologies for Chagas disease and absence of positive epidemiology for Chagas.

The patient satisfaction index after the surgery(s) was graded from 1 to 5, adopting the following parameters: 1 - worse: symptoms increased; 2 - bad: 
symptoms remained; 3 - regular: light improvement, 4 - good: substantial improvement; 5 - excellent: complete recovery. Have also been object of this study: professional occupations and duration of the activity, possible contacts with powerful and dangerous chemicals during these activities; alterations in the nervous system; existence of a previous surgery for idiopathic achalasia; autoimmune disease diagnosis; record of a family member with a diagnosis of idiopathic achalasia; existence of consanguinity in the family and in what level; use of tobacco or alcohol, frequency and duration of use; any other consideration found relevant. Weight loss, previous relevant emotional factor and use of medication were also observed.

\section{RESULTS}

This series was based on 17 men and 16 women; the mean age was 36 years; duration of dysphagia three years and weight loss $13,5 \mathrm{~kg}$. The procedures were 29 cardiomiotomies (88\%), two mucosectomies (6\%) and two esophagectomies (6\%). The complications were $21 \%, 0 \%$ and $100 \%$, respectively. The complications of mucosectomies and esophagectomes were not significant due to small numbers.

The classification of the megaesophagus was: grade 1: $30 \%(n=10) ; 2: 39 \%(n=3) ; 3: 21 \%(n=7)$ e $4: 9 \%$ $(n=3)$. Twenty two patients (67\%) had other associated diseases in the gastrointestinal tract mostly gastritis and/ or esophagitis.

Satisfaction level towards the surgical treatment results was: 29 (88\%) had significant improvement; 2 (6\%) reported a light improvement and other 2 maintained the symptoms.

Previous surgery for achalasia was related by 15 patients (45.5\%) and 9 were submitted to other abdominal or gastrointestinal surgery.

In relationship to their occupations, seven were agriculturists (21\%); six religious (18\%); four (12\%) in construction or domestic services; three (9\%) in carpentry or cleaning services; gardening two patients (6\%). Three of the patients (9\%) had never executed any profession. The remaining had different occupations.

In relationship to strong chemicals (possibly harmful), 19 patients (58\%) reported the contact. The most frequent were herbicides reported by 9 patients (27\%) in which 4 (12\%) declared use of liquids derived from glyphosate; 3 (9\%) had intense contact with thinner and $2(6 \%)$ reported contact with powdered lime (one accidental ingestion). Other chemicals reported were kerosene, paint remover, PVC glue, resins, stain remover, sulfates, diesel, bleach and strong acids.

Immunity related illnesses in this series were present in 10 patients (30\%). Two (6\%) had bronchitis; one scleroderma and osteoarthritis, 5 (15\%) allergic exuberant episodes with insect bites, particular drugs or food allergy. One of these patients was hospitalized for this reason and three quoted suggestive symptoms of colagenosis by describing its inflammatory characteristics.

Family history of achalasia or similar symptoms was obtained in 6 (18\%) with esophagus diseases besides gastroesophageal reflux.

Consanguineous marriages were found in 6 (18\%) patients. In five (15\%), inbreeding could not affect them because it was among cousins or uncles in the first degree. Another patient reported his parents as cousins in the third degree.

In relationship to nervous system disorders, five patients $(15 \%)$ reported a history of seizures, four in childhood and one in adulthood.

Thirteen patients (39\%) reported smoking and 14 (42\%) alcohol problems in a minimum of five years.

Emotional factors related were: 26 patients (79\%) reported no important emotional factor related to the beginning of symptoms, most of which were derived from family problems (48\%). Eleven (33\%) said that they had done psychological treatment and/or psychiatric treatment, confirming the importance of these problems at the time.

Use of drugs was reported by 13 (39\%), continuous medication or other drugs before the symptoms started. Eight of these (24\%) used psychiatric medications, the most prevalent was diazepam (12\%) and phenobarbital (6\%). There were also reports of antihypertensive drugs, fluoxetine, antibiotics, replacement of T4, haldol, illicit drug unspecified, drugs for ovarian cyst treatment and scleroderma.

Typical childhood viral infections (varicella $70 \%$, mumps 58\%, measles 52\%) were present in 29 patients (88\%). Interesting, one patient had rubella immediately before dysphagia started.

\section{DISCUSSION}

Studies concerning to achalasia are current in scientific literature, mainly focusing pathophysiology and structural changes. It is known, for example, that about $90 \%$ of cases of cardia biopsies, inflammatory infiltrate with a predominance of T-lymphocytes are found around the nerve fascicle and ganglion cells of the esophagus. In addition, the plexus of Auerbach is degenerate or significant loss of their fibras ${ }^{21}$. The inflammatory response specific to certain viruses such as measles, chickenpox, and more recently, the herpes virus type 1 , has been greatly focused on many study ${ }^{10,20}$. The importance of serological tests and, in some cases, DNA tests has been recently evidenced ${ }^{6}$.

Other recent studies point out that the amount of interstitial cells of Cajal of the esophagus - responsible for motility and called the pacemaker of the GI tract -, can be greatly reduced or markedly increased (by 
compensatory mechanism) in patients with idiopathic achalasia, which would indicate two different mechanisms responsible for the disease ${ }^{16}$. When studying the motor behavior of the esophagus, once again it is noticed the difference within the group of patients, whereas, by comparing the motor response to esophageal swallow simple and multiple swallows in 20 patients with untreated idiopathic achalasia, some patients showed increased motor activity in multiple swallows, others had inhibited motor activity and some no motor response to any swollow ${ }^{22}$.

When comparing the findings between the chagasic and idiopathic achalasia, it became clear after reviewing of the literature, that the excitatory effect is larger in Chagas disease, which should justify the finding of greater pressure on lower esophageal sphincter in idiopathic achalasia14,17,21. The duration of dysphagia seems to be lower in patients and idiopathic dilation of the esophagus, more pronounced in chagasic $c^{8,9,14}$ patients.

Briefly, it is likely that idiopathic achalasia is related to autoimmune disorder and that this disorder has a multifactorial etiology. There seems to be several diseases with multiple causes and unknown, many of the possibly associated ${ }^{11}$ factors.

The patients profile is already known: young people, usually younger than 40 years, similar prevalence between sexes, shorter duration of dysphagia accompanied by significant weight loss, incipient megaesophagus (usually grade I or II) and good surgical resolution ${ }^{11,13,14,19}$.

The presence of previous surgery in most patients, especially abdominal and/or GI tract, could reflect attempts to correct other diseases, possibly secondary to megaesophagus, or recurrences.

The occupation does not seem to establish strong correlation, since they were very diverse. The most relevant were agricultural labor (21\%) and office work (18\%).

The exposure to chemicals, especially herbicides (27\%), and exposition to derivatives of glyphosate resulted in complaints of epigastric pain and conjunctivitis, typical of this type of poisoning. Knowing the various negative effects that these substances can cause, it is possible to question the possibility of, in patients with predisposition to develop the idiopathic achalasia, this exposure to the herbicide act as a triggering factor. Exposure to other agents alone do not appear to be responsible for alterations.

In relation to immune system diseases, $30 \%$ of patients possibly carried some of these alterations. Idiopathic achalasia is currently regarded as an

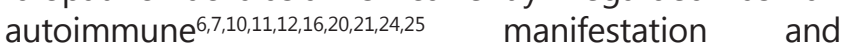
associated to other diseases of this same nature. It should be noted that this number may be even higher, since many of these late-onset diseases and patients operated for idiopathic achalasia are usually young.

The $18 \%$ family history of esophageal symptoms seem compatible, at least in part, to the idiopathic achalasia, and suggest genetic tendency in the family. The history of consanguinity in the families of these $18 \%$ does not seem to be of great relevance. Besides, it is difficult to obtain the percentage rate, because some people fear of having any conversation on this matter, and also the lack of information about these data within a traditional family. It should be noted that the possible genetic component, with familial occurrence, has been studied specifically in other articles s,15,23. $^{2}$.

Since achalasia is a disease that affects the intramural nervous plexus $8,8,10,11,16,20,21$ investigation on other diseases of the nervous system may be recommended. Among all patients $15 \%$ had a history of seizures, $12 \%$ in childhood. This rate is higher than the one normally found in populations.

Smoking and alcohol consumption (39\% and $42 \%$ ) were not as prevalent as in cases of esophagus and stomach cancer, for example. Taking into account the multifactorial hypothesis, these types of cancer may actually be associated in some cases, for they are always potentially harmful substances. Moreover, some patients believed in the relation of these habits to the worsening of other symptoms and even opening of the disease.

The continuous use or overuse of drugs did not revealed anything particularly conclusive. The high rate of use of psychiatric medications called attention to a fact not yet appreciated nor studied in other researches: the emotional factor attached to the disease. In interviews, when asked if passed by significant emotional problems at the time prior to the onset of symptoms, $79 \%$ of patients responded positively, especially $48 \%$ reporting various family problems. Approximately 33\% of patients also declared having psychiatric or psychological treatment, determining strictly that those emotional problems were serious. This number can also be underestimated because many patients do not feel comfortable to report this type of problem in one interview.

Surprisingly, for more than one time, the patient companion wanted to know details of the work with the interviewer and many were categorical in stating that the patient was going through major emotional problems before they develop the disease. In addition, there are very specific cases where the patient started reporting symptoms after the death of very close relative, parents' divorce, separation from spouse and to long-term relationship. With this works contribution, the emotional factor precedes the disease appears to be of great relevance. Surely this still depends on further study for definitive characterization of their importance in this disease.

Finally, as found in other studies, may be association to some infections ${ }^{10,12,20,21}$ specially those from childhood. Stands the fact that many patients do not remember having these infections in childhood. It was the interviewer who gave small simple details that differentiate these diseases, in the attempt of achieving the most reliable data possible. Thus, $88 \%$ 
of patients said they had suffered from at least one of the following diseases: varicella (70\%), mumps (58\%) and measles (52\%). Among them, three patients reported having rubella, and one of them, reported the opening of dysphagia after the disease. Although not fully reliable data can be stimulating new serological studies or even DNA, evaluating whether patients with idiopathic achalasia are more frequently affected even some of these diseases than by some mechanism not yet elucidated.

\section{CONCLUSIONS}

The idiopathic esophageal achalasia is probably an autoimmune disease, which seems to be highly related to emotional problems.

\section{AGRADECIMENTOS}

Ao Programa Institucional de Bolsas de Iniciação Científica - PIBIC, Bolsa SAE/Unicamp.

\section{REFERENCES}

1. Andreollo NA, Lopes LR.; Brandalise NA, Leonardi LS. Acalásia idiopática do esôfago: análise de 25 casos. GED 1996; 15: 151-5.

2. Annese $V$, Napolitano G, Minervini MM, Perri F, Ciavarella $\mathrm{G}$, Di Giorgio $\mathrm{G}$ et al. Family occurrence of achalasia. J Clin Gastroenterol. 1995; 20: 329-30.

3. Ceneviva R, Ferreira-Santos R, Dos Santos JS, Mente ED, Sankarakutty AK. Alterações cronológicas do perfil dos pacientes e da modalidade de tratamento cirúrgico do megaesôfago chagásico. Acta Cir Bras. 2002; 17: 125-28.

4. Coelho JCU. Aparelho Digestivo Clínica Cirúrgica. Editora Medsi. 1996; volume 1.

5. Costa DG, Barros SGS, Grüber AC, Lopes $A B, C$ Filho $M L$, Freitag $C P$. Acalasia na doença de Chagas é diferente de acalasia idiopática? Experiência do Hospital de Clínicas de Porto Alegre. Porto Alegre:Rev HCPA \& Fac Med Univ Fed Rio Gd do Sul. 2002; 22:5-10.

6. Dhamija R, Tan KM, Pittock SJ, FoxxOrestein A, Benarroch E, Lennon VA. Serologic Profiles Aiding the Diagnosis of Autoimmune Gastrointestinal Dysmotility. Clin Gastroenterol Hepatol. 2008; 6: 988-92.

7. Dantas RO. Idiopathic achalasia and Chagasic megaesophagus. J Clin Gastroenterol. 1988; 10:1315.20. Park W, Vaezi MF. Etiology and pathogenesis of achalasia: the current understanding. Am J Gastroenterol. 2005; 100: 1404-14.
8. Dantas RO. Comparação entre acalásia idiopática e acalásia conseqüente à doença de Chagas: revisão. Arq Gastroenterol. 2003; 40:126-30.

9. Dantas RO, Aprile LR. Esophageal contractions in Chagas disease and in idiopathic achalasia. J Clin Gastroenterol. 2005; 39: 863-68.

10. Facco M., Brun P, Baesso I, Constantini M, Rizzetto C, Berto A et al. T Cells in the Myenteric Plexus of Achalasia Patients Show a Skewed TCR Repertoire and React to HSV1 Antigens. Am J Gastroenterol. 2008; 103:1598-609.

11. Farrokhi F, Vaezi MF. Idiopathic (primary) achalasia. Orphanet J Rare Dis. 2007; 26: 238.

12. Feldman M., Esophageal achalasia syndromes. Am J Med Sci. 1988; 295: 60-81.

13. Garcia Juniro C, Araujo OF, Murro AL, Traballi AL, Andreollo NA. Idiopathic achalasia mistakenly diagnosed as anorexia nervosa. Rev Bras Psiquiatr. 2008; 30:168.

14. Herbella FAM, Oliveira, DRCF, Del Grande JC. Are idiopathic and chagasic achalasia two different Diseases? Dig Dis Sci. 2004; 49: 353-60.

15. Kaar, TK, Waldron R, Ashraf MS, Watson JB, O’Neill M, Kirwan WO. Familial infantile esophageal achalasia. Arch Dis Child. 1991; 66: 1353-54.

16. Kilic A, Luketich JD, Landreneau RJ, Owens SR, Krasinskas AM, Schuchert MJ. Alterations in the Density of Interstitial Cells of Cajal in Achalasia. Dig Dis Sci. 2007; 53: 1488-92.

17. Lemme EMO, Vargas SSM, Andrade SRv, Correa VLF. Acalasia de cárdia: estudo retrospectivo de 107 pacientes. ARS Curandi. 1985; 18: 24-38.

18. Mascarenhas LG, Camara-Lopes LH, Jurema B, Ferreira-Santos R. Padronização técnica da radiologia do megaesôfago. X Congr Bras Gastroenterol. 1958.

19. Oliveira GC, Lopes LR, Andreollo NA, Coelho Neto, JS. O megaesôfago tratado cirurgicamente: perfil epidemiológico dos pacientes operados no Hospital de Clínicas da Universidade Estadual de Campinas entre 1989 e 2005. Rev Soc Bras Med Trop. 2008; 41: 183-88.

20. Park, W., Vaezi, M.F. Etiology and pathogenesis of achalasia: the current understanding. American Journal of Gastroenterology. 2005; 100: 1404-14

21. Raymond L, Lach B, Shamji FM. Inflammatory aetiology of primary oesophageal achalasia: an immunohistochemical and ultrastructural study of Auerbachs plexus. Histopathology. 1999; 35: 445-53.

22. Savojardo D, Mangano M, Cantu P, Penagini R. Multiple rapid swallowing in idiopathic achalasia: evidence for patients heterogeneity. Neurogastroenterol Motil. 2007; 19: 263-69.

23. Stein DT, Knauer CM. Achalasia in monozygotic twins. Dig Dis Sci. 1982; 27: 630-40.

24. Wong RK, Maydonovitch CL, Metz SJ, Baker Jr, JR. Significant DQwl association in achalasia. Dig Dis Sci 1989; 34:349-52.

25.Zilberstein B, De Cleva R, Gabriel AG, Neto, SG, GamaRodrigues JJ. Congenital achalasia: facts and fantasies. Dis Esophagus. 2005; 18: 335-37. 